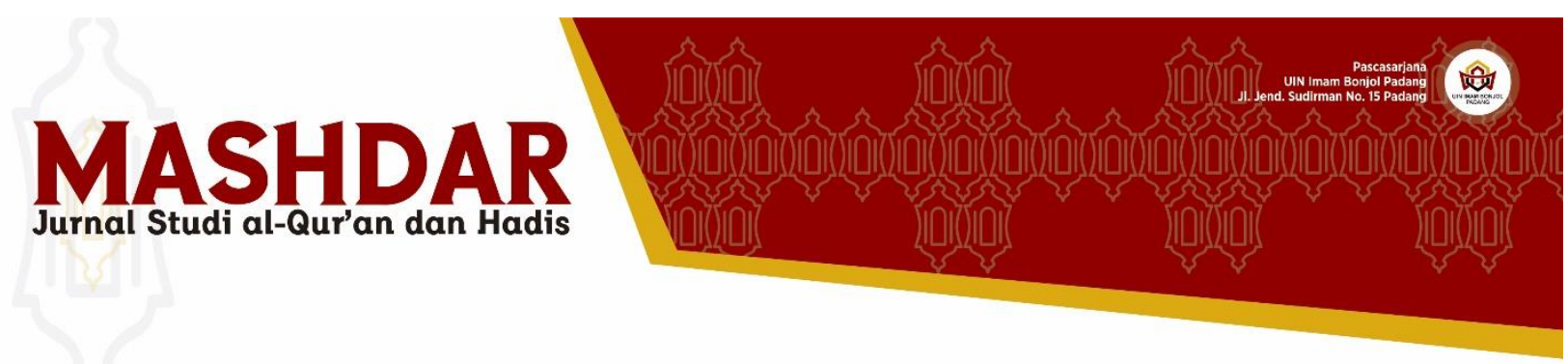

\title{
Interpretasi Semiotika Ferdinand De Saussure dalam Hadis Liwa dan Rayah
}

\author{
M. Dani Habibi \\ UIN Sunan Kalijaga Yogyakarta \\ e-mail : dhany24habibi@gmail.com
}

\begin{abstract}
This article is a study that mengakaji interpretarsi Hadith in the flag Rayah and Liwa or the flag of monotheism. In Indonesia, an organization that uses the banner of Tawheed is the symbol of the organization Hizbut Tahrir Indonesia. There are two warana flag that is black and white. Maising each of the color marked Laa illaaha illaa Allah Muhammad Messenger of God and both have a different meaning. In the context of the history of Liwa and Rayah flag used by the Prophet Muhammad and the cultural context and Rayah Liwa flag is used to establish the Khilafah state. With the legitimacy that the flag of Tawheed is the flag of victory, so the organization Hizbut Tahrir Indonesia using the flag as a form would be the establishment of system of government that has the ideology of Khilafah. Hizb ut-Tahrir insists that the flag Liwa and Rayah not the flag but the flag of Islam. Semiotic analysis of Ferdinand de Saussure, With the theory of semiotics consisting of four concepts, but in this study the researchers only used two concepts among which the first signifiant and signifie both langue and parole. As the shape of the object flag Hizbut Tahrir Indonesia and hadith texts about Liwa and Rayah become the object of focus in this study.
\end{abstract}

Keywords : Hadith Liwa and Rayah; Hizbut Tahrir Indonesia; Semiotics Ferdinand de Saussure

\begin{abstract}
Abstrak
Artikel ini merupakan penelitian yang mengakaji interpretarsi hadis nabi dalam bedera Rayah dan Liwa atau bendera tauhid. Di Indonesia organisasi yang menggunakan simbol bendera tauhid adalah organisasi Hizbut Tahriri Indonesia. Bendera tersebut ada dua warana yaitu hitam dan putih. Maising-masing dari warna tersebut bertulisan Laa illaaha illaa Allah Muhammad Rasul Allah dan keduanya mempunyai makna yang berbeda. Dalam konteks sejarah bendera Liwa dan Rayah digunakan oleh Nabi Muhammad dan pada konteks budaya bendera Liwa dan Rayah digunakan untuk mendirikan negara Khilafah. Dengan legitimasi bahwa bendera Tauhid adalah bendera kemenenagan sehingga organisasi Hizbit Tahrir Indonesia menggunakan bendera tersebut sebagai wujud akan berdirinya sistem pemerintahan yang beridiologikan Khilafah. Hizbut Tahrir menegaskan bahwa bendera Liwa dan Rayah bukan benderanya melainkan bendera Islam. Analisis semiotika Ferdinand De Saussure. Dengan teori semiotikanya yang terdiri dari empat konsep, namun dalam penelitian ini peneliti hanya menggunakan dua konsep diataranya adalah yang pertama signifiant dan signifie dan kedua kosep langue dan parole. Sebagai bentuk obyek bendera Hizbut Tahrir dan teks hadis tentang liwa dan rayah menjadi objek fokus dalam penelitian ini.
\end{abstract}

Kata kunci : Hadis Liwa dan Rayah; Hizbut Tahrir Indonesia; Semiotika Ferdinand De Saussure

\section{PENDAHULUAN}

Indonesia dengan negara yang mempunyai penduduk Muslim terbanyak didunia menajadi sebuah media untuk mengembangkan paham-paham tentang keisalaman sepeti organisasi Hizbut Tahrir Indonesia. Hizabut Tahrir Indonesia merupakan organisasi Islam yang bergerak 
116 | Mashdar : Jurnal Studi al-Quran dan Hadis, Vol.1, No.2, (2019)

dibidang dakwah. Padamulamnya organisasi

Hizbut Tahrir didikikan oleh Taqiyuddin an-

Nabhani pada tahun 1953. Organisasi Hizbut

Tahrir mempunyai sebuah tujuan yakni mengembalikan kejayaan Islam melalui penegakan negara Khilafah Islamiyah. Penyatuan pemerintahan berbasis sitem Khilafah dari berbagai penjurudunia salah satu misi besar Hizbut Tahrir. Pada tahun 1992 Hibut tahrir masuk ke Indonesia dan menjadi organisasi Islam konserfatif dan fundamentalis. Karena dalam mempunayi sebuah ideologi kembali ke Al-Qur'an dan Sunah sebagai sumber hukum Islam yang mutkal kebenarannya. Pemahaman tekstual ketika memahami Al-Qur'an dan Sunah menjadikan organisasi ini radikal dan tidak sedikit negara-negara yang menolak organisasi Hizbut Tahrir termasuk Indonesia. $^{1}$

Pasca Orde Baru, proses demokrarsi tidak hanya ditandai dengan munculnya partai-partai politik. Melainkan juga bermunculan kelompok-kelompok gerakan Islam termasuk HTI. Sehingga pada pasca Orde Baru, kelompok Islam HTI mengidentifikasikan sebagai kelompok

\footnotetext{
${ }^{1}$ Siti Fatkhiyatul Jannah, "Diskursus Negara Antara Nahdlatul Ulama dan Hisbut Tahrir Indonesia di Jawa Timur," Paradigma 1, no. 3 (28 Agustus 2013): hlm 2, http://jurnalmahasiswa.unesa.ac.id/index.php/paradi gma/article/view/4143.

${ }^{2}$ Syamsul Arifin, “Gerakan Hizbut tahrir dan Realitas Politik Islam Kontemporer di Indonesia: Tafsir Sosial Atas Hizbut Tahrir," Al-Tahrir: Jurnal
}

pergerakan perubahan dengan penawaran baru berupa idiologi dan sistem pemerintahan Khilafah. ${ }^{2}$ Secara harfiah HTI atau Hizbut Tahrir mempunyai makna “ parati pembebasan", didalam bahasa arab kata hizb berati partai dan at-tahrir berati pembebasan. Artinya bahwa Hizbut Tahrir adalah sebuah gerakan partai Islam yang bertujuan menyatukan umat Muslim diseluruh dunia dengan ideologi dan sistem Khilafah ${ }^{3}$.

Pada saat melakukan kegiatan terbuka maupun tertutup, Hizbut Tahrir selalu mengibarkan bendera yang bernama Liwa dan Rayah. Bendera tersebut masing-masing terdapat tulisan lafaz Laa illaaha illaa Allah Muhammad Rasul Allah. Bendera liwa adalah bendera yang berwarna putih dan bendera rayah mempunyai warnah hitam. Kedua bendera tersebut masing-masing mempunyai makna yang berbeda. Dalam konteks budaya ketika menganalisa liwa dan rayah terbagi menjadi tiga unsur diantaranya sistem budaya, aktivitas, dan artafak. Sistem budaya yang terdiri dari kosep, gagasan, ideologi pemikiran, nilai

Pemikiran Islam 14, no. 1 (1 Mei 2014): 4, https://doi.org/10.21154/al-tahrir.v14i1.80.

3 Deni Junaedi, "Bendera Hizbut Tahrir Indonesia Daerah Istimewa Yogyakarta"kajian Konteks Sejarah, Budaya dan Estitika Semiotis," Jurnal Kawistara 2, no. 3 (22 Desember 2012): 265, https://doi.org/10.22146/kawistara.3938. 
dan norma-norma atau jenisnya yang bersifat abstrak. Sedangkan aktivitas yaitu suatu tindakan dalam prilaku budaya dan artefak adalah berupa benda ciptaan manusia. Idelogi yang tersusun dalam sebuah sistem pemerintahan Khilafah melalui simbol bendera HTI disusun untuk menyerang atau mendukung suatu misi atau maksud tertentu. Oleh sebab itu tidak heran bahwa sistem pemerintahan yang di bangun Khilafah di tolak diberbagai negara termasuk Indonesia karena ideologi yang diperjuangkan berbeda atau berbenturan dengan ideologi Pancasila. ${ }^{4}$ Dengan menggunakan bendera liwa dan rayah sebagai tanda dimana eksistensi keberadaan kelompok HTI bergerak dan melakukan kegiatan dakwah-dakwahnya.

\section{Dengan menggunakan} pendekatan semiotika dan meminjam teori Ferdinand De Saussure, peneliti mencoba untuk menganalisa problem tanda berupa bendera liwa dan rayah dalam konteks organisasi HTI. HTI dengan Benderanya tersebut sudah menjadi legitimasi kebenaran mutlak oleh mereka bahwa bendera liwa dan

\footnotetext{
${ }^{4}$ David Kaplan dan Albart A. Manners “ Teori Budaya", trj, Landang Simatupang. (Yogyakarta: Pustaka Pelajar .2012).hlm 154

${ }^{5}$ Syafieh Syafieh dan Nurbaiti Nurbaiti, "Potret Karakteristik Kepemimpinan Perempuan"
}

rayah adalah bendera yang digunakan oleh rasulullah. Dengan memperhatikan kosep signifier (penanda) dan signifind (Petanda) juga dengan memperhatikan langue dan parole.

\section{PERSPEKTIF METODOLOGI}

Istilah semiotika modern diperkenalkan oleh dua tokoh yaitu Ferdinand de Saussure (1857-1913) dan Charles Sanders Peirce (1839-1914). Dua tokoh inilah yang sangat berpegaruh dalam linguistik dan semiotik. Kedua tokoh tersebut masing-masing mempunyai konsep seperti Saussure dengan konsep tanda dan penanda dan Pierce mempunyai konsep sign, object dan interpretant ${ }^{5}$. Namun dalam penelitian ini peneliti akan berfokus pada aplikasi teori Ferdinand De Saussure sebagai analisis obyek dalam hal ini adalah bendera Hizbut Tahrir Indonesia HTI.

Ferdinand De Saussure dilahirkan di kota Jenewa pada tanggal 26 November pada tahun 1857. Ia dilahirkan dari keluarga yang sangat terkenal di kotanya. Dengan keberhasilanya dalam bidang ilmu bahasa atau linguistik beliau mendapat sebutan

(Analisis Semiotika Surat Al-Naml: 23-44)," Jurnal At-Tibyan: Jurnal Ilmu Alquran Dan Tafsir 3, no. 1 (9 Agustus 2018): 54, https://doi.org/10.32505/tibyan.v3i1.477. 
118 | Mashdar : Jurnal Studi al-Quran dan Hadis, Vol.1, No.2, (2019)

bapak linguistik. Saussure lahir sezaman dengan Email Durkheim. Sejak kecil ia sudah mempunyai banyak karya berupa Essai dibidang bahasa. Dan pada tahun 1874 ia mulai memulai belajar bahsa Sansekerta. Kiprahnya dibidang linguistik semakin terlihat ketika pada tahun 1880 ia berhasil mempertahankan tesisnya tentang kasus genetatif mutlak dalam bidang bahasa Sansekerta ${ }^{6}$.

Saussure memang terkenal dengan sistem tanda dan penanda. Namun dalam sejarah ia tidak pernah mencetak sebuah buku melainkan setiap ada kuliah atau kuliah umum catatan-catatan dari uraian diskusinya dicatat oleh murid-muridnya lalu dijadikan sebuah outline. Salah satu karya yang telah terbit adalah sebuah buku yang berjudul Course in General linguistics. Kemudian karya tersebut menjadi sebuah karya yang sangat berpengaruh dibidang kebahasaan atau Linguistik. Dan karya itulah yang dinamakan dengan istilah "strukturalisme".

Dalam kajian semiologi misalnya, Saussure menegaskan bahwa sistem tanda memiliki tiga aspek, yaitu itu sendiri yaitu Pertama (sing) atau aspek material baik

6 Kaelan " Filsafat Bahasa Semiotika dan Herrmeneutika” ( Yogyakarta : Paradigma. 2009). hlm. 181

7 Ferdinand de Saussure "Cours de Linguistique General" trj. Rahayu S. Hidayat. (Yogyakarta. Gajah Mada Press.1996). hlm.374. berupa (tanda, suara, bentuk, gambar maupun gerak). Kedua aspek penanda (singnifer). Dan yang ketiga aspek petanda (singnified $^{8}$ Sehingga hubungan antara tanda dan penanda bersifat arbiter (bebas). Namun didalam sebuah tanda tentu memilki nilai-nilai tertentu (value) sedangkan menurut Saussure tanda-tanda tersebut direlasikan dengan sistem tanda-tanda yang lain (sintagma) yang akan bisa menjadikan perbedaan (difference) ${ }^{9}$.

\section{PEMBAHASAN}

\section{Sejarah Bendera Liwa dan Rayah}

Dalam sejarah bendera liwa dan rayah terbentuk di kota madinah pada tahun 622, dan ketika Nabi Muhammad memerintahkan penggunaan liwa (bendera) dan rayah yang berarti panji keislaman. Liwa yang berwana putih dan rayah berwarna hitam. Hal tersebut terdapat dalam hadis nabi yang berbunyi :

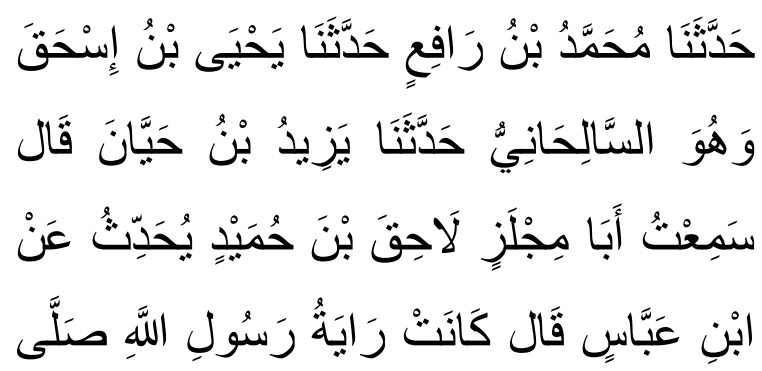

${ }^{8}$ Wildan Taufiq, "Ideologi di Balik SimbolSimbol Surga dan Kenikmatan dalam Ayat-Ayat AlQur'an," Desember 2008, 156, http://publikasiilmiah.ums.ac.id/handle/11617/181.

${ }^{9}$ Ferdinand de Saussure "Cours de Linguistique General" trj. Rahayu S. Hidayat. (Yogyakarta. Gajah Mada Press.1996). hlm.7. 


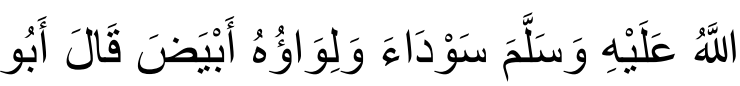

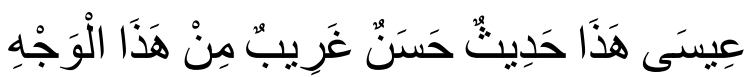
مِنْ حَدِيَثِ ابْنِ عَبَّاسِ

Telah menceritakan kepada kami Muhammad bin Rafi' berkata, telah menceritakan kepada kami Yahya bin Ishaq, yaitu As Salihani- berkata, telah menceritakan kepada kami Yazid bin Hayyan ia berkata; Aku mendengar Abu Mijlaz Lahiq bin Humaid menceritakan dari Ibnu Abbas ia berkata, "Bendera Rasulullah shallallahu 'alaihi wasallam berwarna hitam dan umbul-umbulnya berwarna putih." Abu Isa berkata, "Hadits ini derajatnya hasan gharib melalui jalur ini, dari Ibnu Abbas.

Liwa dan rayah memang dulu digunakan oleh nabi Muhammad saw sebagai tanda pemerintahan Islam waktu itu. Namun, didalam konteks saat ini tanda yang disebut liwa dan rayah digunakan oleh ormas HTI sebagai bendera ideologis ${ }^{10}$ Khilafah Islamiyah. Menjadi masalah jika dalam hadis liwa dan rayah tidak tertulis kalimat tauhid. Berbeda dengan bendera liwa dan rayah yang digunakan oleh HTI. Bendera tersebut berwarna hitam dan putih yang masing-masing bertulisan kalimat

\footnotetext{
${ }^{10}$ Masnun Masnun dan Zusiana Elly Triantini, "Spiritualitas Islam, Khilafah Islamiyah dan Gerakan
}

bertulisan Laa illaaha illaa Allah Muhammad Rasul Allah. Dibawah ini adalah gambar bendera liwa dan rayah yang digunakan oleh ormas Hizbut Tahrir Indonesia.

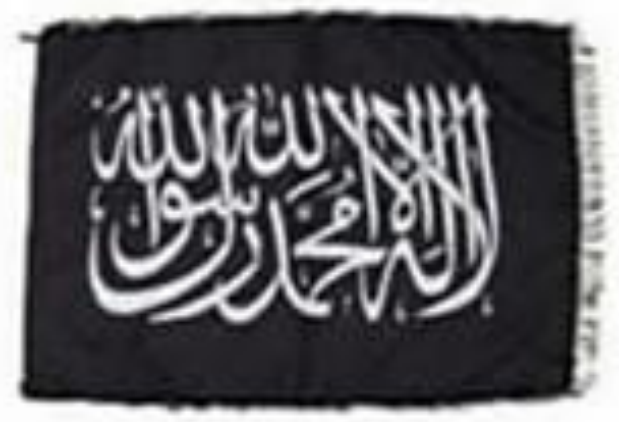

RAYAH

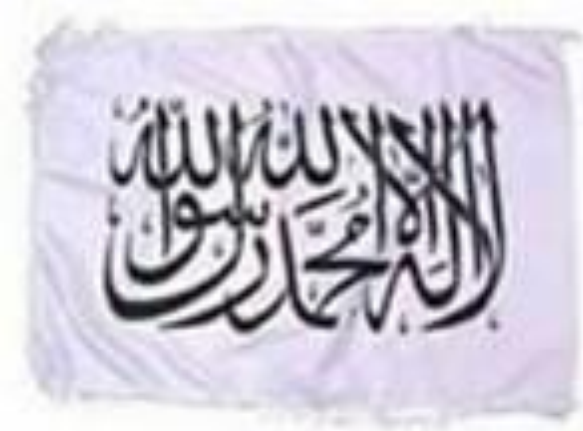

LIWA'

Garmbar 1: Liwa berwarna dasar putih dengan kalimat sahadat berwarna hitam

(Foto: Dani Habibi, 2018)

Melalui bendera tersebutlah, Hizbut Tahir menyebarkan panji-panji idiologis politik kepada masyarakat Muslim. Sehingga mereka mempunyai anggapan bahwa bendera yang rasulullah adalah

Politik Hukum Ingkar Nkri (Studi terhadap Gerakan Politik Hizbut Tahrir di Indonesia)," Istinbath: Jurnal Hukum Islam IAIN Mataram 15, no. 2 (2016): 196. 
120 | Mashdar : Jurnal Studi al-Quran dan Hadis, Vol.1, No.2, (2019)

bendera yang sama digunakan oleh Hizbut Tahrir. Dengan mengibarkan bendera tersebutlah panji-panji keislaman akan menjadi lebih kuat dan lebih sesuai dengan yang diajarkan oleh nabi Muhammad saw. Namun pada umumnya bendera liwa dan rayah yang digunkana oleh nabi untuk peperangan. Liwa yang berada dekat pada pemimpin tertinggi dan ruyah digunakan untuk komandan perang ${ }^{11}$. Sebagai konteks budaya, sebuah bendera memang menjadi sebuah identitas yang menunjukan eksistensinya didalam masyarakat. Baik yang berfungsi sebagai tanda didaerah, identitas kelompok, dan simbol pertempuran. Namun dalam konteks ini, peneliti berfokus pada sebuah tanda berupa simbol bendera rasulullah sebagai identitas kenegaraan.

\section{Problem Interpretasi Berdera Hizbut} Tahrir Indonesia

Bendera HTI diklaim bendera yang dikabarkan oleh rasulullah dengan kata lain siapa yang mengibarkan bendera rasulullah maka ia termasuk kedalam golongannya ${ }^{12}$. Simbol berupa bendera identitas organisasi Hizbut Tahrir Indonesia dinilai tidak layak

11 Deni Junaedi, "Bendera Hizbut Tahrir Indonesia Daerah Istimewa Yogyakarta"kajian Konteks Sejarah, Budaya dan Estitika Semiotis," Jurnal Kawistara 2, no. 3 (22 Desember 2012): 267, https://doi.org/10.22146/kawistara.3938

12 Arifin, "Gerakan Keagamaan Baru dalam Indonesia Kontemporer," Komunika Jurnal dakwah dan Komukasi hlm 6. dikibarkan di Negara Kesatuan Replublik Indonesia. Sebab sebagaian besar masyarakat memandang bahwa bendera HTI adalah bedera yang menjadikan idiologi bangsa seperti Indonesia menjadi rapuh. Namun, bagi masyarakat penganut Hizbut Tahrir menilai bendera liwa dan rayah adalah bendera rasulullah.

Sebenarnya bendera liwa dan rayah menjadi kontofersi ketika didalamnya terdapat idiologi tertentu yang bertujuan merusak idiologi yang sudah ada di tiap-tiap negara seperti Indonesia. Kebangkitan organisasi Hizbut Tahrir di Indonesai memang sangat di waspadai karena dapat merusak sistem dan idiologi bangsa. ${ }^{13}$ Perbentuaran dua idiologi yang mempunyai visi dan misi berbeda menimbulkan konflik. Sehingga setiap orang jika membawa bendera liwa dan rayah di Indonesia maka dinilai sebagai pengikut Hizbut Tahrir Indonesia.

\section{Analisis Interpretasi Berdera Hizbut}

\section{Tahrir Indonesia}

Dalam penelitian ini, peneliti menggunakan pendekatan semiotika dalam meninterpetasikan ulang simbol bendera

13 Rosi Selly, "Globalisasi dan Kebangkitan Khilafah Islamiyah Dalam Perspektif Pemikiran Hizbut Tahrir," 29 Agustus 2008, 28, http://repository.uinjkt.ac.id/dspace/handle/1234567 89/7538. 
tauhid dalam organisasi Hizbut Tahrir Indonesia. Dengan menggunakan pendekatan semiotika yang digagas oleh Ferdinand de Saussure peneliti akan mencoba untuk menafsirkan kembali simbol bendera HTI yang bersumber sari sebuah hadis Nabi tentang bendera.

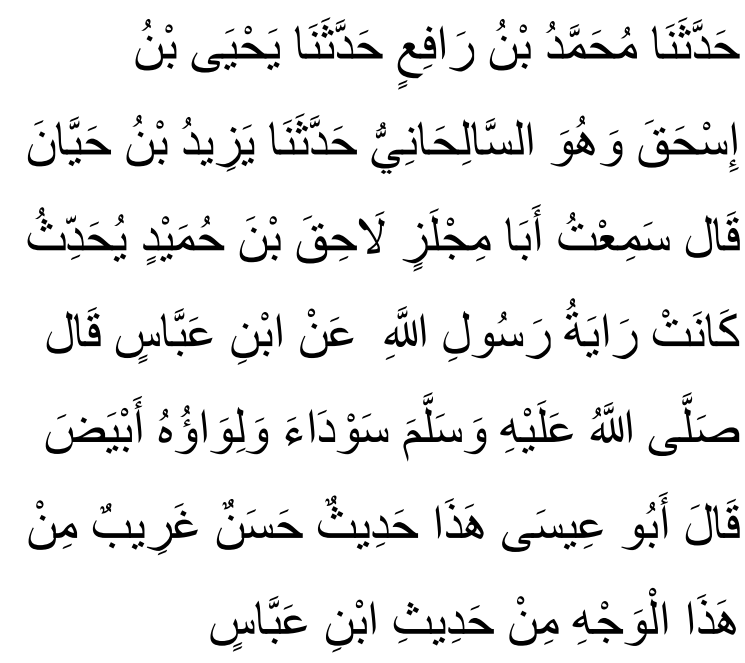

Saussure mempunyai kerangka teoritis yang ia bangun yaitu keraka tersebut seperti langue, parole dan langage. Didalam buku yang berjudul Cours de Linguistique Gernerale karya Fardinand de Saussure yang sudah diterjemahkan menjadi Pengantar Linguistik Umum dijelaskan bahwa yang dimaksud dengan parole adalah keseluruhan apa yang diajarkan oleh orang, termasuk kontruksi-kontruksi individu yang muncul dari ucapan penutur ${ }^{14}$. Jelasnya yang dimaksud dengan istilah parole ialah manifestasi individu dari bahasa. Didalam

\footnotetext{
${ }^{14}$ Ferdinand de Saussure "Pengantar Linguistik Umum" trj. Rahayu S. Hidayat. (Yogyakarta. Gajah Mada Press.1996). hlm 6
}

masyarakat tentunya banyak ditemukan parole-parole yang mempunyai relasi kepada realitas. Sehingga gabungan dari parole-parole dalam kaidah bahasa oleh Saussure disebut dengan langue.

$$
\text { Langue adalah keseluruhan }
$$
kebiasaan yang didapatkan dari masyrakat. Terjadinya komunikasi antara satu parole dengan parole yang lain sehingga membentuk suatu pemahaman yang klektif di masyarakat. Kejadian seperti ini sering dialami oleh masyarakat, lebih-lebih didalam masyarakat majemuk yang didalamnya terdapat banyak aliran dan suku. Sehingga mengerucut pada penelitian ini yang berfokus pada interpretasi objek Liwa dan Rayah didalam hadis nabi diatas dengan menggunakan pendekatan semiotika dan teori Fardinand de Saussure.

Didalam buku yang Pengantar Linguistik Umum, Saussure mendefinisiskan beberapa istilah dalam teorinya seperti, Parole, Langue, Sinkronik dan Diakronik. Parole adalah tuturan, tiap-tiap individu yang menjadi sebuah satu kesatuan sistem yang mentuk norma-norma kolektif didalam masyarakat ${ }^{15}$. Jika merujuk pada teks hadis diatas parole-parol yang muncul didalam masyarakat dahulu menjadikan lagitiammsi individu berupa liwa yang sering diucapkan

15 Ferdinand de Saussure "Pengantar Linguistik Umum" trj. Rahayu S. Hidayat. (Yogyakarta. Gajah Mada Press.1996). hlm.25. 
122 | Mashdar : Jurnal Studi al-Quran dan Hadis, Vol.1, No.2, (2019)

oleh masyarkat pada zaman nabi sebagai identitas bendera.

Lalu parole-parole tersebut menjadi satu kesatuan dalam sistem yang menjadi legitimasi kolektif Langue seperti liwa sebagai bendera pemerintahan. Langue bersifat konveksi yang dapat diterima oleh masyarakat yang siap untuk dipakai dan dari pendahulu. Artinya jika Liwa dan Rayah menajadi langue atau legitimasi kolektif yang sudah ada sejak zaman nabi. Kesepakatan konveksi berupa liwa sebagai bendera dan Rayah sebagai ajaran memang sudah ada sejak zaman nabi Muhammad saw. Dalam kemunculanyapun tidak begitu saja pasti mempunyai historitas sebab musabab kemunculannya.

Saussure mempunyai pandangan bahwa untuk bisa melihat lebih jauh, bagaimana sebuah simbol terbentuk maka ia mempunyai sebuah istilah Sinkronis dan diakronis. Sinkronis adalah kata atau makna yang tidak bisa dirubah dan diakronis adalah makna yang dapat berubah dikarnakan faktor historis. ${ }^{16}$ Sinkronis bersifat umum yang tidak mengharuskan. Artinya didalam langue tidak ada satu kesatuan utuh yang dapat menjamin dan memlihara keteraturan dalam tiap-tiap butir dalam parole. Aturan sinkronis hanya mengungkapkan kelompok

16 Kaelan “ Filsafat Bahasa Semiotika dan Herrmeneutika” ( Yogyakarta : Paradigma.2009).hlm yang ada dan aturan sinkronis mengatur keadaan tiap-tiap objek. Sedangkan diakroni kebalikan dari sinkronis. Diakroni adalah faktor-faktor dinamis yang bisa menghasilakan dampak, suatu yang dikerjakan. Akan tetapi ciri yang mengharuskan kurang cukup untuk bisa menerapkan istilah aturan atau fakta yang evolutif.

Dalam penerapanya terdapat beberapa komponen penting dalam membangun interprretasi bendera HTI berupa liwa dan rayah dengan pendekatan semiotika Fardinand de Saussure. Terdapat teks yang tidak bisa berubah maknanya dan teksnya dari dulu hingga sekarang yang disebut parole. Liwa berati bendera " parole" yang didalam teks hadis tersebut mempunyai cerita historis sebagai identitas didalam pemerintahan nabi Muhammad saw. Lalu liwa yang disebut oleh nabi didalam teks hadis diatas menjadi parole-parore lain. Sehingga dari parole yang banyak diucapkan oleh para sahabat menjadi satu kesatuan utuh dalam interpertasi bendera liwa adalah bendera pemerintahan.

Dalam perkembangnya parole menjadi satu bangunan interpretasi yang menjadi legitimasi kebenaran mutlak oleh

191. Lihat, Ferdinand de Saussure "Pengantar Linguistik Umum" trj. Rahayu S. Hidayat.(Yogyakarta.Gajah Mada Press.1996).hlm 
organisasi Hizbut Tahrir Indonesia yaitu liwa adalah bendera Nabi Muhammad saw.

Sassure mempunyai istilah diakrini sebagai makna yang selalu berkembang mengikuti zaman dan mempunyai faktir historis. Salah satu sejarah kemunculan bendera tersebut karena sebagai penanda kekuasaan atau pemerintahan nabi Muhammad saw. Namun dalam perkembanganya, bendera liwa dan rayah digunakan oleh HTI sebagai identitas idiologis. Transformasi makna dan perubahan simbol liwa dan rayah pada zaman rasul dan yang digunakan oleh HTI disebabkan oleh beberapa faktor. Diantaranya sebagai berikut :

1. Mengembalikan politik Islam yang saat ini telah dilupakan dan diganti oleh sistem kapitalisme dan liberalisme ${ }^{17}$.

2. Menegakakan syari'at Islam.

3. Menumbuhkan semangat juang kembali peradaban Islam pada masa nabi.

4. Menjadikan sistem pemerintahan yang dipimpin oleh satu Khilafah. ${ }^{18}$

Dari beberapa faktor diatas sudah mulai tergambarkan bahwa bendera yang menajadi identitas oleh organisasi Hizbut Tahrir Indonesia merupakan identitas

${ }^{17}$ Syaiful Arif, "Kontradiksi Pandangan HTI Atas Pancasila," Jurnal Keamanan Nasional 2, no. 1 (1 Mei 2016): 24, https://doaj.org.

${ }^{18}$ Masnun dan Triantini, "Spiritualitas Islam, Khilafah Islamiyah dan Gerakan Politik Hukum bendera idiologi politik. Dengan kata lain, simbol bendera tersebut sudah bertrensformasi menjadi bendera yang mempunyai makna idiologis.

\section{SIMPULAN DAN REKOMENDASI}

Bendera liwa dan rayah memang bendera yang digunakan oleh rasulullah ketika memimpin pemerintahan kala itu. Namun, bendera yang digunakan merupakan bendera yang tidak bertulisan kalimat tauhid dan tidak mempunyai idiologi Khilafah. Sehingga ketika organisasi Hizbut Tahrir Indonesia menggunakan bendera liwa dan rayah yang bertulisakan kata tahuid tidak sedikit masyarakat Indonesia mengklaim bahwa itu merupakan bendera yang tidak sesuai dengan idiologi bangsa Indonesia yaitu pancasila.

Merujuk pada pemikiran Ferddinad de Saussure kdalam interpretasi simbol bendera HTI, menyimpulakan bahwa setiap parole-parole menjadi satu kesatuan sistem utuh dan kolektif. Sehingga menjadi langue yang membangun sistem, norma-norma tertentu sesuai dengan yang diharapakan oleh masyarakat.

Bendera Hizbut Tahrir Indonesia mengandung idiologi yang bertentangan

Ingkar Nkri (Studi terhadap Gerakan Politik Hizbut Tahrir di Indonesia)," 199. 
124 | Mashdar : Jurnal Studi al-Quran dan Hadis, Vol.1, No.2, (2019)

dengan idiologi Pancasila. Dikarnakan

ketika masyarakat Hizbut Tahrir Indonesia mengibarkan panji-panji keislaman dan bendera liwa dan rayah maka secara tidak langsung visi dan misi menjadi tujuan HTI diorasikan. Tidak heran bahwa masyarakat

\section{DAFTAR PUSTAKA}

Kaelan "Filsafat Bahasa Semiotika dan Herrmeneutika", Yogyakarta : Paradigma.2009.

Saussure, Ferdinand. De. "Cours de Linguistique General" trj. Rahayu S Hidayat.Yogyakarta: Gajah Mada Press, 1996.

David Kaplan dan Albart A. Manners “ Teori Budaya", trj, Landang Simatupang. Yogyakarta: Pustaka Pelajar.2012.

Arif, Syaiful. "Kontradiksi Pandangan HTI Atas Pancasila." Jurnal Keamanan Nasional 2, no. 1 (1 Mei 2016). https://doaj.org.

Arifin, Syamsul. "Gerakan Keagamaan Baru dalam Indonesia Kontemporer: Tafsir Sosial Atas Hizbut Tahrir." Al-Tahrir: Jurnal Pemikiran Islam 14, no. 1 (1 Mei 2014): 117-38. https://doi.org/10.21154/altahrir.v14i1.80.

Fatkhiyatul Jannah, Siti. "Diskursus Negara Antara Nahdlatul Ulama dan Hizbut Tahrir Indonesia di Jawa Timur." Paradigma 1, no. 3 (28 Agustus 2013).

http://jurnalmahasiswa.unesa.ac.id/index.ph p/paradigma/article/view/4143.

Junaedi, Deni. "Bendera di Hizbut Tahrir Indonesia Daerah Istimewa Yogyakarta (Kajian Konteks
Indonesaia meniali bendera tersebut adalah bendera kemunafikan idiologi.

Sejarah, Konteks Budaya, dan Estetika Semiotis)." Jurnal Kawistara 2, no. 3 (22 Desember 2012).

https://doi.org/10.22146/kawistara.3 938

Masnun, Masnun, dan Zusiana Elly Triantini. "Spiritualitas Islam, Khilafah Islamiyah dan Gerakan Politik Hukum Ingkar NKRI" (Studi terhadap Gerakan Politik Hizbut Tahrir di Indonesia)." Istinbath: Jurnal Hukum Islam IAIN Mataram 15, no. 2 (2016): 193-215.

Selly, Rosi. "Globalisasi dan Kebangkitan Khilafah Islamiyah Dalam Perspektif Pemikiran Hizbut Tahrir," 29 Agustus 2008. http://repository.uinjkt.ac.id/dspace/ handle/123456789/7538.

Syafieh, Syafieh, dan Nurbaiti Nurbaiti. "Potret Karakteristik Kepemimpinan Perempuan" (Analisis Semiotika Surat Al-Naml: 23-44)." Jurnal AtTibyan: Jurnal Ilmu Alquran Dan Tafsir 3, no. 1 (9 Agustus 2018): 5268.

https://doi.org/10.32505/tibyan.v3i1 .477.

Taufiq, Wildan. "Ideologi di Balik SimbolSimbol Surga dan Kenikmatannya dalam Ayat-Ayat al-Quran," Desember 2008. http://publikasiilmiah.ums.ac.id/han dle/11617/181. 